Turkish Psychological Counseling and Guidance Journal

Türk Psikolojik Danışma ve Rehberlik Dergisi
Ayaz, Tomar, Can \& Satıc1 (2021)

Vol: 11 Number: 63 Page: 591-602 ISSN: 1302-1370

\title{
Autonomy Support and Children's School Attachment: Motivation as a Mediator
}

\author{
Özerklik Desteği ve Cocuklarm Okula Bağhlĭğ: Motivasyonun Araculı Rolü
}

\section{Ayşe Ayaz $\odot$, İsmail Hakkı Tomar $๑$, Gürhan Can $\odot$, Seydi Ahmet Satıcı $₫$}

\begin{tabular}{l}
\hline Authors Information \\
Ayşe Ayaz \\
Psychological Counselor, Ministry of \\
National Education, Gaziantep, \\
Turkey a.kolkesen@gmail.com \\
İsmail Hakk1 Tomar \\
Assistant Professor, Hasan Kalyoncu \\
University, Gaziantep, Turkey \\
ihtomar@gmail.com \\
Gürhan Can \\
Professor, Hasan Kalyoncu \\
University, Gaziantep, Turkey \\
gurhancan49@gmail.com \\
Seydi Ahmet Satıcı
\end{tabular}

\section{Seydi Ahmet Satici}

Associate Professor, Artvin Çoruh

University, Artvin, Turkey

sasatici@gmail.com

\begin{tabular}{l}
\hline Article Information \\
\hline Keywords \\
School Attachment \\
Teacher's Autonomy Support \\
Intrinsic Motivation \\
Identified External Motivation \\
Introjected External Motivation \\
Anahtar Kelimeler \\
Okula Bağlanma \\
Öğretmenin Özerklik Desteği \\
İçsel Motivasyon \\
Özzdeşleşmiş Dişsal Motivasyon \\
İçselleştirilmiş Dişsal Motivasyon \\
Article History
\end{tabular}

Received: $19 / 11 / 2021$

Revision: 07/12/2021

Accepted: 10/12/2021

\begin{abstract}
The present study examined the mediating role of motivation in the association between autonomy support and children's school attachment. The study participants consisted of 437 primary school students (232 girls and 205 boys) selected from six schools in a province located in Turkey's southeast region. A hypothesized model was developed and tested by structural equation modeling on cross-sectional data. The data were collected via The School Attachment Scale for Children and Adolescents, The Scale for Motivation in Education, and The Short Form of the Learning Climate Scale. The results indicated that autonomy support had an indirect effect on school attachment through internal motivation. Contrary to these findings, it has been determined that neither identified external motivation nor introjected external motivation affected attachment to the school's directly and indirectly.
\end{abstract}

Cite this article as: Ayaz, A., Tomar, I.H., Can, G., \& Satıc1, S.A. (2021). Autonomy support and children's school attachment: Motivation as a mediator. Turkish Psychological Counseling and Guidance Journal, 11(63), 591-602. 


\section{INTRODUCTION}

The school's mission is to ensure the students' academic development and facilitate their physical, psychological, and social development at an optimum level. The school's success in fulfilling these responsibilities is closely related to student's attachment to school and happiness at school. "School attachment is a concept that involves students' behaviors and thoughts based on their experiences and feelings related to school" (Fredricks et al., 2005). According to Finn, school attachment (1993) is the feeling that students belong to a school and adopt their goals. Goodenow (1992) stated that school attachment involves respecting students' freedom rather than a simple sense of love and closeness.

Students who are bounding and happily attending the school become calmer with a stronger inner motivation. They, therefore, are more sufficient socially and academically, with the desire to participate much more in extra-curricular activities (Carr, 2011). When students feel that they attach to the school, they feel safe and comfortable, and they are proud of the school they belong to (Maddox \& Prinz, 2003). Students who have adapted to a new school, who are going there happily and thinking they belong, gradually decrease their negative qualities and increase their positive ones. Some related literature findings have reported that students attached to a school, and feeling that they belong to school display less disruptive behavior than the ones showing no attachment to school (Simons-Morton et al., 1999).

Additionally, some authors stress that students attached to the school avoid smoking, drinking alcohol or substance abuse, committing a crime, and violent behavior (Dorbusch et al, 2001). Thus, they experience less emotional and peer problems, and more favorable well-being than the ones having no attachment to school (Karaşar \& Kapç1 2016). In one of the earliest studies on school attachment, Hirschi (1969) reported that in addition to an individual's connection to family, friends, or religion, school attachment was also a deterrent for committing crimes.

Many researchers have pointed out that many factors affect school attachment. Among these factors, such as symptoms of depression and anxiety (Yildiz \& Kutlu 2015), quality of life (Savi-Çakar, 2011), satisfaction with life, school anger (Savi-Çakar \& Karataş, 2017), self-respect (Karaşar \& Kapç1, 2016), and internal locus of control (İhtiyaroğlu \& Demir, 2015) are the factors related to individual factors. Apart from these, some school-related factors such as loss of interest in school, school burnout (Altuntaş \& Sezer, 2017), school bullying (Duy \& Y1ldız, 2014), teachers' and friends' social support (Karababa et al., 2017), teachers' autonomy support, and educational motivation (Tyler et al., 2016) are the other factors affecting school attachment.

Teacher's autonomy support has a particular importance on student attachment to the school. It refers to an atmosphere in which the teacher does not force the students to behave in a certain way but instead encourages them to be themselves (Ryan \& Deci,2004). Being in such an environment for about 25-30 hours a week facilitates the teacher's supportive role. Teachers who support students' independence provide students with meaningful choices and opportunities to take ownership and initiative of their schoolwork to influence their interests (Ryan \& Deci, 2020). Teachers can support students' autonomy by nurturing students' intrinsic motivation sources, providing them with explanatory rationales, using informative language, allowing students to form their learning patterns, and accepting students' expression of their emotions (Reeve, 2009). Some authors pointed out that the teacher has a vital role in the students' attachment to the school. In this context, Mengi (2011) argues that social support perceived by students from their teachers increases students' devotion to the school, while Osterman (2000) argues 
that students who trust their teacher attach to the school at a high level. More importantly, Krane et al. (2016) stated that the teacher-student relationship's quality, including teacher support, is associated with dropout or actual dropout.

According to Self-Determination Theory, motivation, which is the reason and driving force behind the behavior (Deci \& Ryan, 1985), affects students in many ways, such as their academic achievements, attitudes towards school, preferences, and attachments to the school. However, students perform all school-related behaviors either because they enjoy them or feel obliged to do so. For example, if a student attends school willingly and joyfully, the reason for this situation, which is an indicator of the student's attachment to school, is intrinsic motivation. All behaviors arising from intrinsic motivation are autonomous because individuals do these behaviors based on their own free will and personal pleasure (Can, 2015). Contrary to this, all behaviors arising from extrinsic motivation are partly self-determined and controlled. Individuals do extrinsically motivated actions to avoid internal or external pressures against his / her free will. However, types of integrated and identified extrinsic motivation are more autonomous than introjected and external types. (Deci \& Ryan, 1985).

Autonomy support is the support given by those in authority positions to an individual during decisionmaking process willingly, and also the process of seeing the outcomes due to their choice, thereby making them choose the appropriate one. Thus, as Deci and Ryan state (1987), when teachers show respect for their student's preferences and to do so in a flexible and non-pressured manner, they would support their students' autonomy. Moreover, teachers would prepare the foundations for fulfilling their obligations and that of their students more productively (Reeve, 2009). As a matter of fact, in a study conducted with primary school students, Guay et al. (2001) found that communicating with children in a way that supports autonomy increases the child's intrinsic motivation and thus facilitates his/her coping with controlling and repulsive school environments. In a similar study, Vallerand et al. (1997) concluded that the behaviors of teachers, parents, and school administration towards students affect students' perceptions of competence and autonomy.

Consequently, the more the teacher supports the students' autonomy, the higher their school attachment behavior is. Also, it would not be wrong to say that teachers' effects on students' intrinsic motivation, introjected and identified regulation, would also affect school attachment.

\section{The Present Study}

This study aims at determining whether primary school students' perceived autonomy support from their teachers directly affects their levels of school attachment. Also, this study has the purpose of testing whether intrinsic motivation, introjected external regulation, and identified extrinsic regulation affect their school attachment levels or not. One of the ways of preventing negative behaviors in schools, which is one of the social institutions that people are in contact with, is to help students increase their level of attachment to school. This makes researches that will reveal the variables that may have an effect on school attachment important. In the hypothesis model of the research, it has been suggested that the autonomy support that students perceived from their teachers will directly affect their attachment to the school and indirectly through motivation types. 


\section{METHOD}

\section{Participants}

This study's participants were 469 primary school 4th-grade students attending six schools in a province in Turkey. We chose the participants from the six primary schools using the convenience sampling method. After removing the data of 32 students with univariate and multivariate extreme values from the data set, we performed the analysis with the data of 437 students. Detailed information about the participants is in Table 1.

\begin{tabular}{lcc}
\hline Table 1. Descriptive statistic for study variables $\mathbf{( n = 4 3 7 )}$ & & $\mathbf{0}$ \\
\hline Variables & $\mathbf{n}$ & \\
\hline Gender & & 53.1 \\
$\quad$ Female & 232 & 46.9 \\
$\quad$ Male & 205 & \\
Age & & 23.5 \\
$\quad 9$ years & 103 & 66.4 \\
10 years & 290 & 10.1 \\
11 and above & 45 & \\
Participation in Extracurricular Activities & & 69.1 \\
$\quad$ Yes & 302 & 26.8 \\
No & 117 & 4.1 \\
Unspecified & 18 & \\
\hline
\end{tabular}

\section{Ethical Statement}

The author declare that they continue to work in accordance with scientific study ethics and the Helenski declaration in this study. Accordingly, the research was reviewed by the Ethics Committee of Hasan Kalyoncu University and was given permission (E-97105791-050.01.01-5482).

\section{Measures}

The School Attachment Scale for Children and Adolescents (SASCA). This scale, a 5-point Likerttype instrument consisting of 13 items, was developed by Hill (2005). The high points obtained from the scale indicate a high level of school attachment. Savi (2011), who adapted the scale to Turkish, revealed a three-factor structure that explains $58.69 \%$ of the total variance resulting from the exploratory factor analysis. Cronbach's alpha coefficients of the Turkish version of the scale calculated for the subscales varied between .71 and .80 . However, Cronbach's alpha value is .84 for the whole instrument. The testretest reliability coefficient value for a two-week interval is .85 , and the split-half reliability coefficient of this instrument is .78.

The Scale for Motivation in Education (MES). This scale, developed by Vallerand et al. (1989), is a five-point Likert-type scale consisting of four sub-dimensions and 12 items. Kara (2008), who adapted the scale to Turkish, found that the scale explained $63.47 \%$ of the total variance resulting from its exploratory factor analysis. The adapted scale has a four-factor structure as it was in the original. Itemtotal correlations of the scale vary between .60 and .83, and Cronbach's alpha internal consistency coefficients of the subscales (e.g., intrinsic motivation, identified regulation, introjected regulation) vary between .78 and .80 . The Cronbach alpha coefficient value calculated for the whole scale is .84 .

The Short Form of the Learning Climate Scale (LCS). This scale, developed by William et al. (1996), is a 7-point Likert type, a 6-item measuring instrument that aims to measure students' perceived autonomy support from their teachers. The scale was adapted to Turkish by Kandemirci and Cihangir- 
Çankaya (2015). As a result of the exploratory factor analysis, the authors obtained a single factor structure explaining $66.33 \%$ of the scale's total variance. The scale items' factor loads are over .75 , and the Cronbach alpha value for the scale's internal consistency is .88 .

\section{Procedure and Data Analysis}

Data collection tools were applied to the participants in the schools in the sample by the first researcher. We used Lisrel 8.7 to test the hypothetical model and the Sobel test to test the relationships between variables and mediators in the model. Once the scale models' fit indexes had reached the desired level, we tested the hypothetical model and calculated the fit indices.

\section{RESULTS}

The first step of the study was to evaluate the relationships between the variables. The Pearson Moments Correlation Coefficients of the relationship between the study variables are in Table 2.

\begin{tabular}{|c|c|c|c|c|c|}
\hline Variables & 1 & 2 & 3 & 4 & 5 \\
\hline 1. School attachment & - & & & & \\
\hline 2. Autonomy support & $.14^{* *}$ & - & & & \\
\hline 3. Identified external motivation & $.10^{*}$ & $.11^{*}$ & - & & \\
\hline 4. Introjected external motivation & -.06 & $-.13^{* *}$ & .02 & - & \\
\hline 4. Intrinsic motivation & $.21^{* *}$ & $.13^{* *}$ & $.10^{*}$ & $.11^{*}$ & - \\
\hline
\end{tabular}

${ }^{*} p<.05 ;{ }^{* *} p<.01$

The findings revealed that school attachment has a significant and positive relationship with autonomy support $(\mathrm{r}=.14, \mathrm{p}<.01)$, identified external motivation $(\mathrm{r}=.10, \mathrm{p}<.05)$ and intrinsic motivation $(\mathrm{r}=$ $.21, \mathrm{p}<.01)$. The correlation analysis also showed that autonomy support has a significant and positive relationship with identified external motivation $(\mathrm{r}=.11, \mathrm{p}<.05)$ and intrinsic motivation $(\mathrm{r}=.13, \mathrm{p}<$ $.01)$ and a significant and negative relationship with introjected external motivation $(r=-.13, p<.01)$.

\section{Testing the Measurement Models}

Before testing the hypothetical model, we tested the measurement model for each scale. Therefore, the measurement model for the Learning Climate Scale (LCS), Motivation in Education Scale (MES), The School Attachment Scale for Children and Adolescents (SASCA) were each tested separately.

When the consistency indices for the LCS scale model was tested, it was determined as being in perfect fit $(\chi 2 / \mathrm{df}=.34, \mathrm{RMSEA}=0.00, \mathrm{NFI}=1.00, \mathrm{NNFI}=1.00, \mathrm{CFI}=1.00, \mathrm{RMR}=0.01, \mathrm{GFI}=1.00, \mathrm{AGFI}=0.99)$. The fit indices for the MES measurement model upon being tested were also revealed to be of perfect fit $(\chi 2 / \mathrm{df}=.05, \mathrm{RMSEA}=0.00, \mathrm{NFI}=.98, \mathrm{NNFI}=1.02, \mathrm{CFI}=1.00, \mathrm{RMR}=0.01, \mathrm{GFI}=0.99, \mathrm{AGFI}=0.99)$. Finally, the SASCA fit indices were revealed to be at a good level $(\chi 2 / \mathrm{df}=5.26, \mathrm{RMSEA}=0.09, \mathrm{NFI}=.89$, $\mathrm{NNFI}=.89, \mathrm{CFI}=.91, \mathrm{RMR}=0.05, \mathrm{GFI}=0.90, \mathrm{AGFI}=0.85)$. After determining that the fit indices were high enough, we performed the hypothetical research model's next step.

\section{Testing the Hypothetical Model}

The hypothetical model's findings based on autonomy support for school attachment and its motivation types as predictors are in Figure 1. 


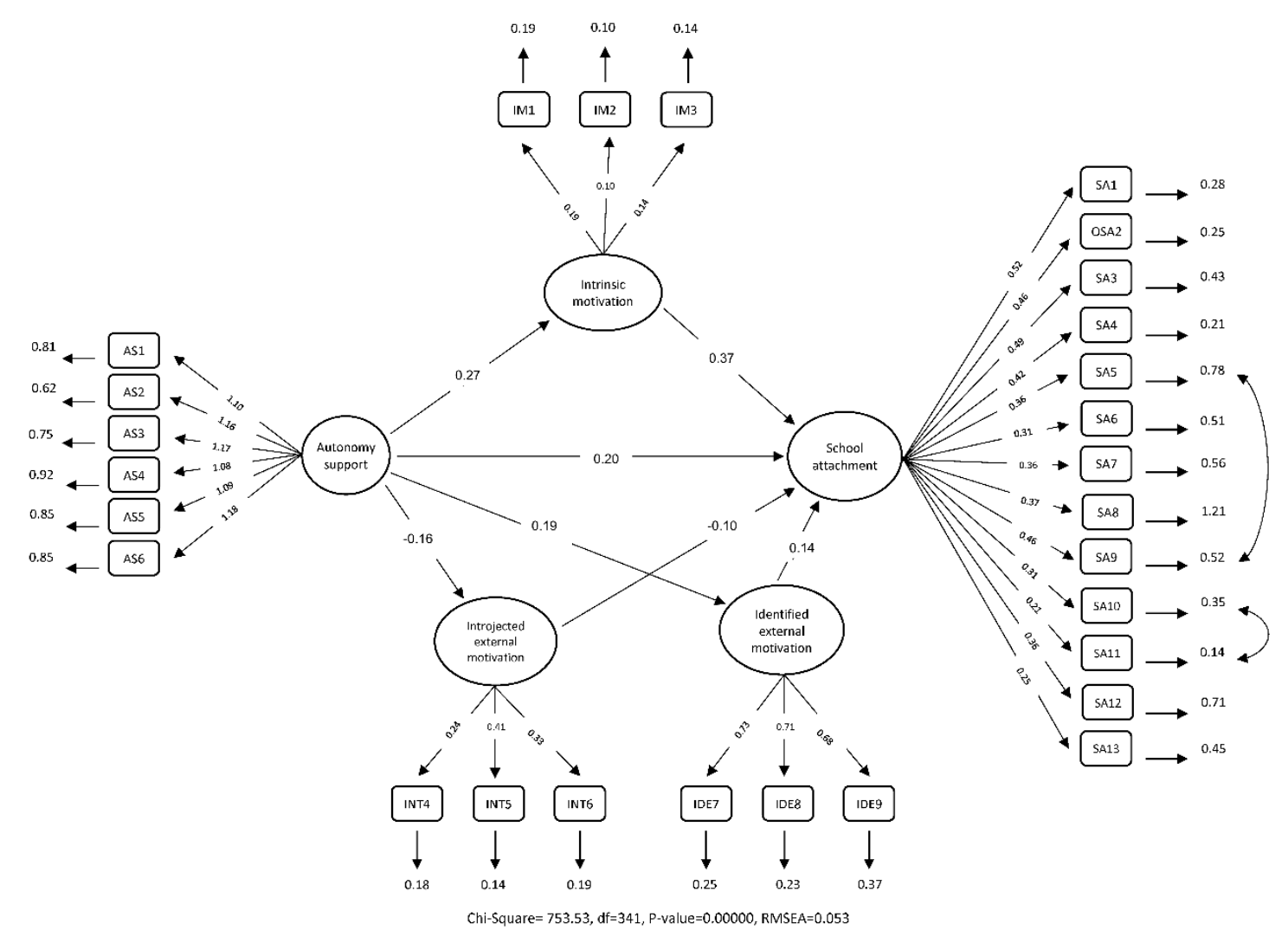

Figure 1. The hypothetical model on the study

As it is laid out in Figure 1, all direct relations are entirely significant. The consistency indices of the model created are shown to be at a good level $\left(\chi^{2} / \mathrm{df}=2.02, \mathrm{RMSEA}=0.05, \mathrm{NFI}=0.89, \mathrm{NNFI}=0.93\right.$, $\mathrm{CFI}=0.94, \mathrm{RMR}=0.04, \mathrm{GFI}=0.87, \mathrm{AGFI}=0.85)$. In addition to this, that autonomy support accounts for $20 \%$ of school attachment is evident. Intrinsic motivation explained $37 \%$ of school attachment, while the identified external motivation explained $14 \%$, and introjected external motivation explained only $10 \%$. While introjected external motivation is negatively related to school attachment, autonomy support, intrinsic motivation, and identified external motivation could be positively related to school attachment.

We applied the Sobel test for each variable to test the indirect effect of autonomy support on school attachment through motivation types. As a result of the Sobel test, the partial mediating impact of autonomy support on school attachment through intrinsic motivation was significant $(2.75, \mathrm{p}<.01)$. While the direct effect of autonomy support on school attachment was .20, we observed that its partial mediation effect through intrinsic motivation increased to .30. The indirect effect of autonomy support on school attachment through identified extrinsic motivation was not significant (1.87, p $>$.05). Finally, we tested the mediating effect of autonomy support on school attachment through introjected extrinsic motivation. Sobel test results revealed that introjected extrinsic regulation mediation was not significant $(1.69, \mathrm{p}>.05)$. 


\section{DISCUSSION}

This study examines teachers' autonomy support on primary school fourth-grade students' attachment to the school. The research has shown that teacher's autonomy support directly affects students to attach the school. The mediating role of intrinsic motivation in the relationship between teacher autonomy support and student attachment to school made a significant contribution to school attachment. While the direct effect of teacher's autonomy support on school attachment was .20, this value increased to .30 through intrinsic motivation. On the other hand, the mediating role of both the identified regulation and the introjected regulation in the relationship between the teacher's autonomy support and school attachment did not significantly contribute to students' school attachment level. The study's finding that teachers' autonomy support has a predictive role on students' school attachment is consistent with Hallinan's (2008) view that teacher behaviors will affect students' feelings about school. Also, this finding is consistent with the research findings suggesting that one of the factors that make up school attachment is teacher support (Libbey, 2004) and that students in schools with positive student-teacher communication have higher school attachment (Ecless et al., 1993) than the other ones. In other words, teachers' support for autonomy increases students' intrinsic motivation, and consequently, their levels of school attachment increase.

On the other hand, the finding of this research regarding the positive effect of intrinsic motivation on school attachment is consistent with Ryan's and Deci's (2000) view that students with high intrinsic motivation see school as more valuable. Also, the findings of Karaşar and Kapç1 (2016), Özdemir (2015) and Demir (2017) suggesting that academic motivation increases students' levels of school attachment is similar to the positive effect of intrinsic motivation on school attachment in this study. The fact that controlled motivation types such as identified regulation and introjected regulation do not significantly affect school attachment suggests that school attachment can only develop in completely free environments where students can behave without doubts and anxiety. Even though the identified and introjected regulations are partially autonomous, they are still alien to individuals' selves since they have been placed or introjected due to internal or external pressures. These qualities of controlled regulations may be one of the reasons why they are not effective in developing school attachment behavior in students.

Although the findings obtained from this study show that teachers' autonomy support affects student attachment to the school directly and indirectly through intrinsic motivation, the correlation coefficients for these effects are pretty low. This situation requires helping teachers improve their current autonomy support practices. For this purpose, some activities to be carried out within the scope of "consultancy services" can be included in school psychological counseling and guidance programs. Thus, school counselors can be an advisor for school administrators, teachers, and other student-related staff in the school so that they can support their students' autonomy more effectively. Also, school counselors can assist teachers in how they can improve students' intrinsic motivation. Such efforts of school psychological counselors will also help all school staff develop a common understanding in activities that can be done to support students' autonomy and improve their intrinsic motivation.

In our study, there are some limitations to consider in interpreting the results. First of all, participants selected from only one province do not allow the research findings to be generalized across the country. Although schools of different socio-economic levels in a region participated in the study, the study sample was a convenience sampling method that requires a generalization of the findings only to schools in the 
study sample and similar schools. The fact that the measurement tools used in this study were not suitable for the first three primary education classes made it obligatory to limit the participants to the final grade (4th.grade). For this reason, the age-related change in school attachment did not examine in this study, and the study was limited to only primary school fourth-grade students.

\section{Conclusion}

In this study, which investigated the effect of perceived autonomy support and motivation from the teacher on primary school students' school attachment, it was found that the teacher's autonomy support had a significant direct effect on school attachment. While the direct effect of teacher's autonomy support on school attachment was .20 , this value increased to .30 through intrinsic motivation. On the other hand, the mediating role of both the identified regulation and the introjected regulation in the relationship between the teacher's autonomy support and school attachment did not significantly contribute to students' school attachment level. 


\section{REFERENCES}

Altuntaş, S. \& Sezer, Ö. (2017). Investigating School Attachment of Secondary School Students. Inönü University Journal of the Faculty of Education, 18(1), 83-97. https://doi.org/10.17679/inuefd.295722

Can, G. (2015). Turkish version of the academic motivation scale. Psychological Reports, 116(2), 388-408. https://doi.org/10.2466/14.08.PR0.116k24w5

Carr, A. (2011). Positive psychology: The science of happiness and human strengths.(2nd ed.) Routledge.

Deci, E. L., \& Ryan, R.M. (1985). Intrinsic motivation and self-determination in buman behavior. Plenum Press.

Deci, E. L., \& Ryan, R. M. (1987). The support of autonomy and the control of behavior. Journal of Personality and Social Psychology, 53(6), 1024-1037. https://doi.org/10.1037/0022-3514.53.6.1024

Demir, Y. (2017). Relationships among internet addiction, academic motivation, academic procrastination, and school attachment in adolescents [Unpublished doctoral dissertation], Inonu University.

Dornbusch, S. M., Erickson, K. G., Laird, J., \& Wong, C. A. (2001). The relation of family and school attachment to adolescent deviance in diverse groups and communities. Journal of Adolescent Research, 16(4), 396-422. https://doi.org/10.1177/07435558401164006

Duy, B., \& Yildız, M. A. (2014). School attachment and loneliness in early adolescents with different bully status. Education and Science, 39(174), 173-188. http://dx.doi.org/10.15390/EB.2014.2435

Eccles, J. S., Midgley, C., Wigfield, A., Buchanan, C. M., Reuman, D., Flanagan, C., \& Mac Iver, D. (1993). Development during adolescence: The impact of stage-environment fit on young adolescents' experiences in schools and in families. American Psychologist, 48(2), 90-101. https://doi.org/10.1037/0003-066X.48.2.90

Finn, J.D. (1993). Student engagement and student at risk. (1.st. Ed). National Center for Education Statistics.

Fredricks, J. A., Blumenfeld, P., Friedel, J. \& Paris, A. (2005). School engagement. In K. A. Moore \& L. Lippman (Eds.), What do children need to flourish?: Conceptualizing and measuring indicators of positive development (pp. 305 321). Springer Science and Business Media.

Goodenow, C. (1992). School motivation, engagement, and sense of belonging among urban adolescent students (ED349364). ERIC. https://eric.ed.gov/?id=ED349364

Guay, F., Boggiano, A. K., \& Vallerand, R. J. (2001). Autonomy support, intrinsic motivation, and perceived competence: Conceptual and empirical linkages. Personality and Social Psychology Bulletin, 27(6), 643-650. https://doi.org/10.1177/0146167201276001

Hallinan, M. T. (2008). Teacher influences on students' attachment to school. Sociology of Education, 81(3), 271-283. https://doi.org/10.1177/003804070808100303

Hill, L. G. (2005). Investigation of a brief measure of school attachment. [unpublished manuscript] Department of Human Development: Washington State University, USA.

Hirschi, T. (1969). Causes of delinquency. (1st Ed.). Univesity of California Press.

İhtiyaroğlu, N., \& Demir, E. (2015). Analysis of the level of students' attachment to school, having different locus of control. The Black Sea Journal of Social Sciences, 7(03), 282-296. https://dergipark.org.tr/tr/pub/ksbd/issue/16232/170005

Kandemirci, D., \& Cihangir Çankaya, Z. (2015, October 7-9). Öğrenme iklimi ölçĕginin Türkşye uyarlanması. [Conference presentation]. 13. National Psychological Counseling and Guidance Congress, Mersin, Turkey.

Kara, A. (2008). Adaptation of the "Echelle de Motivation en Education" scale to Turkish. Ege Journal of Education, 9(2). 59-78. https://dergipark.org.tr/tr/pub/egeefd/issue/4911/67251

Karababa, A., Oral, T., \& Dilmaç, B. (2018). The role of perceived social support and value in prediction of school attachment among secondary school students. Hacettepe University Journal of Education, 33(2), 269-279. https://doi.org/10.16986/HUJE.2017028440 
Karaşar, B., \& Kapç1, E. G. (2016). Examining school attachment and academic success in terms of different variables. Journal of Faculty of Educational Sciences, 49(1), 21-42. https://doi.org/10.1501/Egifak 0000001373

Krane, V., Karlsson, B., Ness, O., \& Kim, H. S. (2016, July, 02). The teacher-student relationship, student mental health, and dropout from upper secondary school: A literature review. Scandinavian Psychologist. https://doi.org/10.15714/scandpsychol.3.e11

Libbey, H. P. (2004). Measuring student relationship to school: attachment, bonding, connectedness, and engagement. Journal of School Health, 74(7), 274-283. https://doi.org/10.1111/j.1746-1561.2004.tb08284.x

Maddox, S. J., \& Prinz, R. J. (2003). School bonding in children and adolescents: Conceptualization, assessment, and associated variables. Clinical Child and Family Psychology Review, 6(1), 31-49. https://doi.org/10.1023/A:1022214022478

Mengi, S. (2011). Relations for the Social Support and Self Efficacy with School Bonding of the Secondary Education 10th and 11th Classes Students [Unpublished master's thesis]. Sakarya University.

Osterman, K. F. (2000). Students' need for belonging in the school community. Review of Educational Research, 70(3), 323-367. https://doi.org/10.3102/00346543070003323

Özdemir, Y. (2015). School burnout in secondary school students: role of homework, school engagement and academic motivation. Adnan Menderes University Faculty of Education Journal of Education Sciences, 6(1), 27-35. https://dergipark.org.tr/tr/download/article-file/399538

Reeve, J. (2009). Why teachers adopt a controlling motivating style toward students and how they can become $\begin{array}{lll}\text { more autonomy } & \text { supportive. Educational }\end{array}$ https://doi.org/10.1080/00461520903028990

Ryan, R. M., \& Deci, E. L. (2000). Self-determination theory and the facilitation of intrinsic motivation, social development, and well-being. American Psychologist, 55(1), 68-78. https://doi.org/10.1037/0003$\underline{\text { 066X.55.1.68 }}$

Ryan, R. M., \& Deci, E. L. (2004). Autonomy Is No Illusion: Self-Determination Theory and the Empirical Study of Authenticity, Awareness, and Will. In J. Greenberg, S. L. Koole, \& T. Pyszczynski (Eds.), Handbook of Experimental Existential Psychology (pp. 449-479). Guilford Press.

Ryan \& Deci (2020). Intrinsic and extrinsic motivation from a self-determination theory perspective: Definitions, theory, practices, and future directions. Contemporary Educational Psychology, 61, 1-11. https://doi.org/10.1016/j.cedpsych.2020.101860

Savi, F. (2011). School attachment scale for children and adolescents: The study of validity and reliability. Elementary Education Online, 10(1), 80-90. https://www.ilkogretim-online.org/fulltext/2181596726058.pdf?1640900629

Savi-Çakar, F., \& Karataş, Z. (2017). Adolescents' self-esteem, school anger and life satisfaction as predictors of their school attachment. Education and Sciences, 42(189), 121-136. http://dx.doi.org/10.15390/EB.2017.6573

Savi-Çakar, F. (2011). School attachment and quality of life in children and adolescents of elementary school in Turkey. Education Research, 9(1), 1465-1471. http://www.interesjournals.org/ER

Simons-Morton, B. G., Crump, A. D., Haynie, D. L., \& Saylor, K. E. (1999). Student-school bonding and adolescent problem behavior. Health Education Research, 14(1), 99-107. https://doi.org/10.1093/her/14.1.99

Tyler, K. M., Stevens-Morgan, R., \& Brown-Wright, L. (2016). Home-school dissonance and student-teacher interaction as predictors of school attachment among urban middle level students. RMLE Online, 39(7), 122. https://doi.org/10.1080/19404476.2016.1226101

Vallerand, R. J., Fortier, M. S., \& Guay, F. (1997). Self-determination and persistence in a real-life setting: toward a motivational model of high school dropout. Journal of Personality and Social Psychology, 72(5), 1161-1176. https://doi.org/10.1037/0022-3514.72.5.1161 
Vallerand, R.J., Blais, M.R., Brière, N.M., \& Pelletier, L.G. (1989). Construction et validation de l'echelle de motivation en éducation (EME). Revue Canadienne des Sciences du Comportement, 21, 323-349. https://doi.org/10.1037/h0079855

Williams, G. C., Grow, V. M., Freedman, Z. R., Ryan, R. M., \& Deci, E. L. (1996). Motivational predictors of weight loss and weight-loss maintenance. Journal of Personality and Social Psychology, 70(1), 115-126. https://doi.org/10.1037/0022-3514.70.1.115

Yildız, M. A., \& Kutlu, M. (2015). An examination of the social anxiety and depressive symptoms as the predictors of school attachment among early adolescent. Mustafa Kemal University Journal of Social Sciences Institute, 12(31), 332-345. https://dergipark.org.tr/tr/download/article-file/183427 


\section{About Authors}

Ayşe Ayaz. She completed her undergraduate degree in the field of Psychological Counseling and Guidance at Gazi University. She received her MA degree in Psychological Counseling and Guidance from Hasan Kalyoncu University. She works as a psychological counselor at a primary school affiliated to the Ministry of National Education. Her research interests include school attachment, autonomy support, motivation, and school satisfaction.

İsmail Hakk1 Tomar. İsmail Hakk1 Tomar completed his undergraduate and MA degree in Psychological Counseling and Guidance from Karadeniz Technical University. He received PhD degree in Gazi University. Dr. Tomar is currently work in in the Department of Psychological Counseling and Guidance at Hasan Kalyoncu University, Gaziantep, Turkey. He is interested in Couple stress and coping, gifted children, positive youth development, life skills, resilience.

Gürhan Can. Gürhan Can received his undergraduate and graduate education from Ankara University and then completed his doctoral education at Hacettepe University. Gürhan Can is currently a professor in the Department of Psychological Counseling and Guidance at Hasan Kalyoncu University, Gaziantep, Turkey. He is interested in Self-Determination Theory, motivation, fear of missing out.

Seydi Ahmet Sat1c1. Seydi Ahmet Sat1c1 received his undergraduate education in the field of guidance and psychological counseling at Sakarya University. He completed his master's and doctorate education in the field of guidance and psychological counseling at Anadolu University. Dr. Satic1 is currently an Associate Professor in the Department of Guidance and Psychological Counseling at the Faculty of Education, Artvin Coruh University. His research interests include forgiveness, revenge, internet and social media addiction, well-being and happiness.

\section{Author Contribution}

This study was conducted by all the authors working together and cooperatively. All of the authors substantially contributed to this work in each step of the study.

\section{Conflict of Interest}

It has been reported by the authors that there is no conflict of interest.

\section{Funding}

No funding support was received.

Note

This study has been produced Ayse Ayaz's master thesis.

\section{Ethical Statement}

This study was completed in accordance with the Helsinki Declaration. In line with this, the study was permitted by Hasan Kalyoncu University, Ethics Committee.

Ethics Committee Name: Hasan Kalyoncu University, Ethics Committee.

Approval Date: 19/11/2021

Approval Document Number: E-97105791-050.01.01-5482 